\title{
IMPLEMENTASI PROGRAM BELAJAR DARI RUMAH (BDR) DALAM PEMBELAJARAN BAHASA INDONESIA PADA MASA PANDEMI KORONAVIRUS
}

\author{
Annisa Tiara Kusuma ${ }^{1}$, Laili Etika Rahmawati ${ }^{2}$ \\ Pendidikan Bahasa dan Sastra Indonesia \\ Universitas Muhammadiyah Surakarta \\ Surakarta, Indonesia \\ e-mail: a310170229@student.ums.ac.id ${ }^{1}$,Laili.Rahmawati@ums.ac.id ${ }^{2}$
}

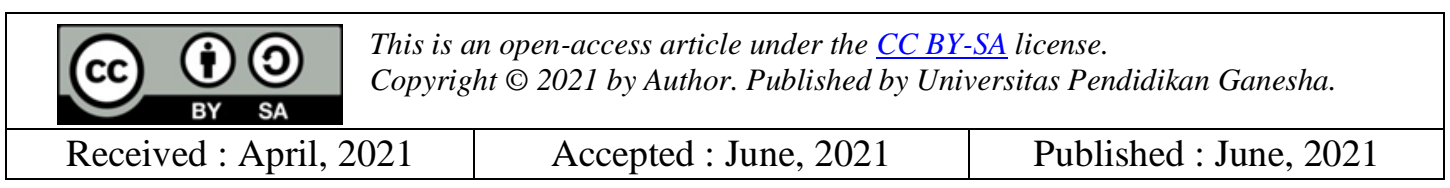

\begin{abstract}
ABSTRAK
Tujuan penelitian ini adalah untuk mendeskripsikan implementasi pembelajaran Bahasa Indonesia pada masa pandemi koronavirus melalui program Belajar Dari Rumah (BDR) pada siswa kelas VIII MTs Terpadu Karanggede Boyolali. Penelitian ini menggunakan metode kualitatif. Teknik pengumpulan data melalui wawancara guru dan angket yang diberikan kepada siswa. Subjek penelitian ini adalah guru Bahasa Indonesia dan siswa kelas VIII Mts Terpadu Karanggede Boyolali. Metode analisis data yang digunakan yaitu analisis interaktif model Milles dan Hubberman. Berdasarkan hasil penelitian perencanaan pembelajaran Bahasa Indonesia yang dilakukan oleh guru meliputi: menyusun KI (Kompetensi Inti) dan KD (Kompetensi Dasar), silabus, RPP (Rencana Pelaksanaan Pembelajaran) untuk satu kali pertemuan, prota (program tahunan) dan promes (program semester), dan kalander akademik. Pelaksanaan pembelajaran Bahasa Indonesia di MTs Terpadu Karanggede Boyolali dengan metode on came-close came. Evaluasi pembelajaran dilakukan melalui peninjauan kembali materi dengan kuis singkat, dan untuk ulangan harian dilakukan dengan mengirimkan soal melalui Google form. Disarankan dalam kegiatan melalui program Belajar Dari Rumah (BDR), guru mampu merancang kegiatan pembelajaran dari perencanaan hingga evaluasi dengan cara yang lebih sederhana, kreatif dan efektif, seperti guru mampu menggunakan aplikasi pembelajaran yang asik, menyenangkan, dan tidak membosankan bagi peserta didik ketika Belajar Dari Rumah (BDR).
\end{abstract}

Kata-kata kunci: belajar; Belajar Dari Rumah; pembelajaran Bahasa Indonesia

\section{ABSTRACT}

The purpose of this study was to describe the planning, implementation, and evaluation of Indonesian language learning during the coronavirus pandemic through the home learning program (BDR) for class VIII students of Integrated MTs Karanggede Boyolali. This study uses a qualitative method. Data collection techniques through teacher interviews and questionnaires given to students. The subjects of this study were Indonesian language teachers and class VIII students of Integrated Mts Karanggede Boyolali. The data analysis method used was the interactive analysis of the Milles and Hubberman model. Based on the results of research planning Indonesian language learning carried out by the teacher, including: Compiling KI and KD, compiling syllabus, compiling lesson plans compiled only one sheet and lesson plans made one meeting, compiling prota and promes, compiling academic calander. The implementation of Indonesian language learning at MTs Terpadu Karanggede Boyolali using the came-close came method. Learning evaluation is carried out by reviewing the material by holding a short quiz, and for daily tests it is done by sending questions via google form. It is recommended that in activities through the 
Learning From Home (BDR) program, teachers are able to design learning activities from planning to evaluation in a simpler, creative and effective way, for example the teacher is able to use learning applications that are fun, fun, and not boring for students when Learning From Home (BDR).

Keywords: learning; learning from home; learning Bahasa Indonesia

\section{PENDAHULUAN}

Kondisi pandemi koronavirus telah mempengaruhi hampir seluruh aspek kehidupan, salah satunya pendidikan. Pendidikan adalah salah satu sektor yang sangat terdampak pada kondisi pandemi ini. Dalam rangka pemenuhan hak peserta didik untuk mendapatkan layanan pendidikan selama darurat penyebaran koronavirus, proses pembelajaran kini dilaksanakan melalui penyelenggaraan Belajar Dari Rumah yang sesuai dalam Surat Edaran Kemendikbud Nomor 4 Tahun 2020 tentang Pelaksanaan Kebijakan Pendidikan dalam Masa Darurat Penyebaran virus koronavirus (Pendidikan et al., 2013).

Dalam menghadapi masa pandemi koronavirus ini, maka pembelajaran dilaksanakan di rumah, sehingga peserta didik tidak perlu datang ke sekolah. Dengan adanya Belajar Dari Rumah (BDR) maka belajar apa saja dari rumah, dengan orang tua sebagai pengganti guru kelas (Ahsani, 2020). BDR diharapkan mampu memutus rantai penyebaran penyakit koronavirus. Siswa pun dihimbau untuk tetap melakukan semua aktivitas di rumah dan selalu menerapkan perilaku hidup bersih dan sehat. BDR ini diharapkan mendukung proses pembelajaran jarak jauh dan mempermudah dalam penyebaran materi kepada peserta didik. Oleh karena itu pendidik juga diharuskan menyiapkan perangkat pembelajaran yang memungkinkan siswa untuk BDR. Penggunaan metode pengajaran yang tepat maupun perilaku dan sikap guru yang efektif dalam mengelola proses belajar mengajar sangat dibutuhkan dalam pembelajaran selama program BDR.

Model pembelajaran merupakan sesuatu proses dari perencanaan atau pola yang digunakan guru sebagai pedoman dalam melaksanakan pembelajaran di kelas (Trianto dalam Rahmatilah et al., 2017). Model pembelajaran mengacu pada pendekatan pembelajaran yang akan digunakan, termasuk di dalamnya tujuan-tujuan pengajaran, tahap-tahap dalam kegiatan pembelajaran, lingkungan pembelajaran, dan pengelolaan kelas. Adapun konsep pembelajaran dengan program Belajar Dari Rumah (BDR) yang dilakukan di MTs Terpadu Karanggede Boyolali dilaksanakan secara asinkron dan sinkron. Pembelajaran dengan asinkron dilaksanakan dengan mengirimkan tautan link Youtube malalui Whatsapp Group yang dapat diakses kapan saja tanpa batasan waktu; dan pelaksanaan pembelajaran secara sinkron dengan memanfaatkan Google form untuk memberikan kuis singkat yang ada batasan waktu dalam pengerjaannya.

Walaupun banyak tenaga pendidik, peserta didik maupun masyarakat yang belum siap menghadapi era revolusi industri 4.0, pembelajaran daring di tengah pandemi koronavirus ini seakan-akan memaksa semua manusia harus siap terhadap perkembangan teknologi saat ini (Siahaan, 2020). Masa-masa awal BDR banyak pendidik dan orang tua merasa kebingungan untuk mencari model pembelajaran yang tepat dan cocok untuk siswanya seperti menyediakan kuota internet hingga membuat materi online. Kondisi pandemi saat ini menyebabkan minat belajar siswa cenderung menurun sehingga dibutuhkan hal-hal yang sifatnya aspiratif dari keinginan siswa, libatkan rencana pembelajaran dengan keinginan dan kondisi siswa sehingga lebih bisa 
diterima dan dijalankan dengan kondisi yang menyenangkan. Sehebat apapun rencana pembelajaran yang dibuat di musim pandemi ini, jika siswa tidak tertarik menjalankannya maka akan sulit bagi guru menjalankan proses pembelajaran yang maksimal.

Rangkaian aktivitas pembelajaran yang dilaksanakan oleh pendidik serta peserta didik untuk menggapai tujuan pembelajaran, yaitu sesuatu deskripsi mengenai tingkah laku yang diharapkan tercapai oleh siswa setelah berlangsung pembelajaran (Hamalik, 2004). Suryosubroto (2002) berpendapat bahwa belajar mengajar bagaikan proses bisa memiliki dua definisi yaitu rentetan tahapan ataupun fase dalam mempelajari sesuatu, dan bisa pula berarti sebagai rentetan aktivitas perencanaan guru, pelaksanaan kegiatan sampai evaluasi.

Pembelajaran Bahasa Indonesia yaitu proses interaksi antara peserta didik dengan sumber belajar pada suatu lingkungan belajar yang berorientasi mentransfer ilmu pengetahuan dan mengembangkan empat keterampilan berbahasa. Pembelajaran Bahasa Indonesia hakikatnya belajar komunikasi yang bertujuan mengembangkan kemampuan menggunakan Bahasa Indonesia dalam segala fungsinya, mulai dari sarana berpikir, bernalar, berkomunikasi, sarana persatuan, dan kebudayaan (Roysa dalam Kusmiarti \& Hamzah, 2019). Kompetensi yang harus dimiliki oleh peserta didik dalam pembelajaran bahasa tertera dalam silabus Bahasa Indonesia, yaitu (1) berbahasa Indonesia dengan penekanan pada kemampuan mendengarkan, membaca, viewing, berbicara dan menulis; (2) mengembangkan kemampuan mendengarkan, membaca, viewing, berbicara, dan menulis melalui media teks; (3) berkomunikasi dalam bentuk tulisan, lisan atau multimodal yaitu sebuah teks yang menggabungkan bahasa dengan media komunikasi lainnya seperti visual, bunyi atau lisan.

Keberhasilan dalam pembelajaran Bahasa Indonesia itu juga bergantung pada proses interaksi yang dimulai dengan minat belajar pelaku pendidikan, yaitu siswa terhadap proses belajar mengajar pembelajaran Bahasa Indonesia. Bahasa Indonesia, seperti yang dikatakan Keraf (2001) bahwa bahasa memiliki fungsi-fungsi tertentu yang digunakan berdasarkan kebutuhan seseorang, yakni sebagai alat berkomunikasi, sebagai alat untuk mengadakan integrasi dan beradaptasi sosial dalam lingkungan atau situasi tertentu, dan sebagai alat untuk melakukan kontrol sosial, menjadi lemah fungsinya di tengah-tengah masyarakat Indonesia masa kini. Bahasa Indonesia merupakan salah satu bidang studi yang memiliki tujuan membekali siswa untuk mengembangkan bahasa di samping aspek penalaran dan hafalan. Dalam proses belajar mengajar seorang pendidik harus dapat menyampaikan materi dengan baik dan mengajak siswa untuk mendengarkan, menyajikan media yang dapat dilihat, memberi kesempatan untuk menulis, mengajukan pertanyaan dan tanggapan sehingga terjadi dialog kreatif yang menunjukkan proses belajar mengajar yang interaktif.

Berdasarkan kondisi yang terjadi selama masa pandemi koronavirus serta beberapa ulasan di atas maka tujuan penelitian ini adalah menganalisis implementasi program Belajar Dari Rumah (BDR) dalam pembelajaran Bahasa Indonesia pada masa pandemi koronavirus pada siswa kelas VIII MTs Terpadu Karanggede Boyolali.

\section{METODE}

Penelitian ini menggunakan pendekatan kualitiatif dengan model studi kasus. Menurut Sugiyono dalam Anggara \& Abdillah (2018) bahwa penelitian kualitatif 
merupakan metode penelitian yang digunakan untuk meneliti pada kondisi obyek yang alamiah, di mana peneliti adalah sebagai instrumen kunci, teknik pengumpulan data menggunakan wawancara mendalam, observasi dan dokumentasi, untuk validasi data dilakukan secara triangulasi (gabungan), analisis data bersifat induktif, dan hasil penelitian kualitatif lebih menekankan makna dari pada generalisasi. Model studi kasus (case study) adalah sebuah model yang memfokuskan eksplorasi "sistem terbatas" (bounded system) atas satu kasus khusus ataupun pada sebagian kasus secara terperinci dengan penggalian data secara mendalam. Beragam sumber informasi yang kaya akan konteks dilakukan untuk penggalian data (Creswell dalam Empati et al., 2017).

Pengumpulan data tentang implementasi program BDR dalam pembelajaran Bahasa Indonesia pada masa pandemi korona yang penilaiannya menggunakan angket berpedoman pada skala likert dengan lima pilihan jawaban. Sedangkan sumber data penelitian ini berupa angket yang diberikan kepada siswa dan hasil wawacara dengan guru. Angket yang diberikan kepada siswa adalah angket implementasi yang diukur menggunakan skala sikap model Likert dengan lima pilihan jawaban. Respon yang diharapkan dari angket adalah setuju maupun ketidaksetujuan dengan pemberian skor untuk butir sebagai berikut: Sangat setuju $(S S)=5$, setuju $(S)=4$, kurang setuju $(K S)=3$, tidak setuju $(\mathrm{TS})=2$, sangat tidak setuju $(\mathrm{STS})=1$.

Pemaparan mengenai teknik pengumpulan data yaitu dengan wawancara dan opbservasi. Wawancara adalah alat yang sangat baik untuk mengetahui tanggapan, pendapat, keyakinan, perasaan, motivasi, serta proyeksi seseorang terhadap masa depannya (Widoyoko dalam M., \& Rusimamto, 2015). Wawancara dilakukan dengan melibatkan guru dan siswa yang melaksanakan pembelajaran Bahasa Indonesia melalui program BDR. Dengan melakukan wawancara, peneliti berharap mengetahui respon siswa dan guru berdasarkan pandangan dan keyakinan dari subjek penelitian. Dari wawancara juga didapatkan informasi terkait dengan bagaimana perencanaan, pelaksanaan, serta bagaimana evaluasi saat pembelajaran Bahasa Indonesia yang dilakukan melalui program BDR di masa pandemi koronavirus. Observasi adalah suatu proses pengamatan dan pencatatan secara sistematis, logis, objektif, dan rasional mengenai beberapa fenomena, baik dalam fenomena sebenarnya maupun dalam fenomena dibuat-buat guna mencapai keberhasilan tertentu yang telah direncanakan (Arifin dalam Munawaroh et al., 2017). Teknik observasi ini digunakan untuk mengamati dan mengetahui kondisi siswa saat melaksanakan pembelajaran Bahasa Indonesia ketika program BDR.

Analisis data yang dilakukan dalam penelitan ini bertujuan untuk memberi makna terhadap data yang telah dikumpulkan. Hasil penelitian yang akan dianalisis secara deskriptif adalah data tentang bagaimana perencanaan, pelaksanaan, serta bagaimana evaluasi saat pembelajaran Bahasa Indonesia yang dilakukan melalui program BDR di masa pandemi koronavirus. Secara skematis proses analisis data menggunakan model analisis data interaktif Miles dan Huberman dapat dilihat pada bagan di gambar 1 berikut : 


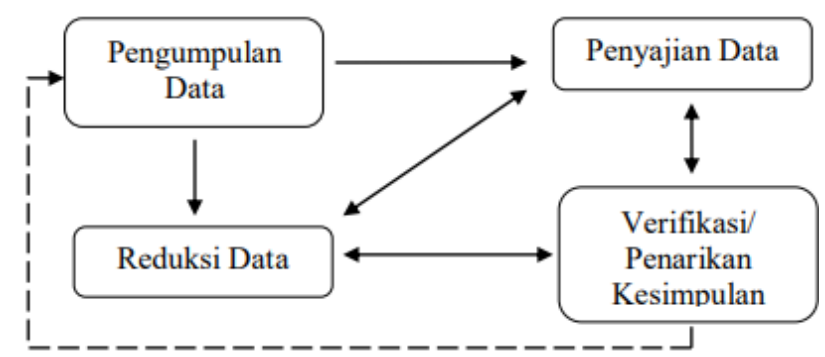

Gambar 1. Skema analisis data interaktif model Miles dan Huberman

\section{HASIL DAN PEMBAHASAN}

Penelitian ini dilakukan pada siswa kelas VIII dan guru mata pelajaran Bahasa Indonesia di MTs Terpadu Karanggede Boyolalipada bulan Maret 2021. Pengumpulan data dalam penelitian ini dilakukan dengan mewawancarai salah satu guru mata pelajaran Bahasa Indonesia kemudian memberikan angket kepada siswa melalui Google form. Angket berisi 11 pertanyaan dengan jumlah responden 20 siswa dari 30 siswa dalam satu kelas. Di bawah ini akan disajikan data mengenai hasil yang ditemukan:

\section{Perencanaan Perangkat Pembelajaran Bahasa Indonesia}

Pada masa pandemi koronavirus seperti ini, MTs Terpadu Karanggede Boyolali melaksanakan kegiatan pembelajaran secara daring. Siswa-siswi, guru, staf dan karyawan di MTs Terpadu Karanggede Boyolali melakukan proses belajar mengajar dan bekerja dari rumah (BDR). Tetapi di masa pandemi koronavirus seperti ini tentunya banyak perubahan dalam hal pelaksanaan kegiatan pembelajaran. Peranan teknologi dalam pendidikan seperti saat ini menjadi sangat vital, sejalan dengan Rogantina dalam Hanifah Salsabila et al. (2020) yang menjelaskan bahwa teknologi sangat berperan aktif dalam meningkatkan mutu pendidikan, meningkatkan efektifitas dan efisiensi proses belajar mengajar sehingga dapat mempermudah dalam mencapai suatu tujuan pendidikan. Teknologi komunikasi yang sangat fungsional dalam kondisi BDR di antaranya aplikasi Whatsapp group, Google Meet, Zoom, Microsoft Teams, dan lainlain.

Implementasi adalah suatu proses untuk melaksanakan ide, program atau seperangkat aktivitas baru dengan harapan orang lain dapat menerima dan melakukan perubahan (Fullan dalam Rahmat, 2017). Dalam implementasi perangkat pembelajaran Bahasa Indonesia program BDR pada saat masa pandemi koronavirus, penggunaan RPP (Rencana Pelaksanaan Pembelajaran) dan silabus tetap digunakan dan menjadi acuan dalam pelaksanaan proses pembelajaran. Saat masa pandemi seperti ini pendidik merencanakan pembelajaran sama halnya seperti perencanaan pembelajaran biasanya. Perencanaan pembelajaran dimulai dari menyusun perangkat pembelajaran yang disesuaikan dengan kurikulum yang sedang diterapkan yaitu Kurikulum 2013. Perencanaan berbentuk perangkat pembelajaran yang disusun oleh pendidik meliputi:

1. KI (Kompetensi Inti) dan KD (Kompetensi Dasar) khususnya pada mata pelajaran Bahasa Indonesia tingkat SMP kelas VIII.

2. Menyusun silabus, seperti biasanya pendidik harus menyusun silabus yaitu rancangan proses pembelajaran bersifat umum yang selanjutnya akan 
diturunkan menjadi RPP. Silabus disusun dengan KI dan KD yang akan disampaikan ke peserta didik.

3. Menyusun Rencana Pelaksanaan Pembelajaran (RPP). RPP disusun sesuai dengan silabus yang telah dibuat. RPP biasanya terdiri dari banyak aspek yang lebih dari satu lembar, tetapi dalam masa pandemi ini RPP hanya disusun menjadi satu lembar saja dan sifatnya adalah Belajar Dari Rumah atau daring dan RPP dibuat setiap satu kali pertemuan. Hal ini sedikit berbeda dengan RPP biasanya yang di dalamnya sudah terdapat beberapa pertemuan yang akan ditempuh dalam satu bab materi.

4. Menyusun Prota (Program Tahunan) dan Promes (Program Semester), tentu kedua perangkat ini tidak dapat dipisahkan ketika menyusun perencanaan pembelajaran. Kondisi pandemi maupun tidak pandemi Prota dan Promes tetap harus di susun.

5. Kaldik (kalender akademik) menjadi perangkat inti untuk menentukan target menyelesaikan setiap bab materi yang akan ditempuh dan menjadi tolak ukur pembuatan Prota dan Promes.

Menyiapkan materi untuk diajarkan kepada peserta didik di saat pandemi ini tentu memiliki keterbatasan antara pendidik dan peserta didik. Persiapan materi dari pendidik tentu yang pertama disesuaikan dengan sumber belajar yang digunakan. Seperti pembelajaran biasanya, sumber belajar berasal dari buku ajar guru dan buku siswa. Tetapi, buku yang seharusnya diterima dalam bentuk cetak harus dikirimkan kepada peserta didik melalui broadcast dalam bentuk file perangkat lunak (PDF). Berbeda halnya dengan sekolah MTs Terpadu Karanggede Boyolali, selain buku paket elektronik yang dikirimkan melalui broadcast, MTs Terpadu Karanggede Boyolali juga mengirimkan buku penunjang berbentuk LKS (Lembar Kerja siswa) yang dikirimkan melalui jasa pengiriman kepada anak didik di rumah. Hal tersebut karena di MTs Terpadu Karanggede Boyolali berbasis pondok pesantren (boarding school) yang notabene seluruh bahan belajar yang ada ditinggalkan di pondok selama santri dipulangkan, maka dari pihak sekolah harus berupaya agar peserta didik dapat maksimal dalam mendapatkan sumber belajar yaitu dengan mengirimkan buku yang mereka butuhkan. Selain buku, pendidik pun juga menambahkan sumber-sumber belajar dari situs online atau kanal Youtube yang dapat diakses peserta didik selama BDR.

Guru sebagai fasilitator dituntut untuk terampil dalam menggunakan media pembelajaran (Astra dan Wahidah 2017; Hanib and Indriwati 2017; Mayasari, et al., 2015 dalam Purbawati et al., 2020). Media pembelajaran adalah segala sesuatu yang dapat digunakan untuk menyalurkan pesan untuk mencapai tujuan pembelajaran. Media di sini harus menjadi media yang benar-benar membantu siswa untuk mencapai tujuan pembelajaran (Kristanto, 2016 dalam Maiti \& Bidinger, 1981). Media ajar yang digunakan pada saat masa pandemi seperti media komunikasi pembelajaran yang dilakukan pendidik MTs Terpadu Karanggede Boyolali yaitu Whatsapp Group, Google Meet, dan Google Form. Ketiga media tersebut cukup membantu pendidik dalam pembelajaran berlangsung. Sehingga pendidik tetap dapat bertatap muka dengan peserta didik meskipun hanya melalui virtual. Media ajar yang digunakan pendidik selama pandemi yaitu Power Point, PDF, dan image, pendidik meringkas materi yang penting untuk diketahui peserta didik dan membuat materi dengan bentuk tayangan Power Point/ PDF/image. Bagi peserta didik yang tidak dapat mengunduh Power Point/PDF karena terkendala jaringan atau aplikasi yang tidak mendukung, pendidik 
menyediakan materi dalam bentuk image suoaya mereka tetap dapat mengunduh dan mendapatkan materi belajar yang sama dengan teman-temannya yang lain.

Suryani dan Agung dalam Harianto (2017) menyatakan bahwa media pembelajaran adalah bahan, alat, atau teknik yang digunakan dalam kegiatan belajarmengajar dengan maksud agar proses interaksi komunikasi pendidikan antara guru dan siswa dapat berlangsung secara tepat guna dan berdaya guna. Adapun media ajar lain yang digunakan di MTs Terpadu Karanggede Boyolali yaitu video edukasi. Selama masa pandemi MTs Terpadu Karanggede Boyolali mencanangkan program video edukasi yang disesuaikan dengan mata pelajaran yang diampu setiap pendidik. Video tersebut kemudian dikirimkan ke channel Youtube MTs Terpadu Karanggede Boyolali. Jadi, dalam proses KBM (Kegiatan Belajar Mengajar) pendidik dapat membagikan video yang sudah diproduksi kepada peserta didik dan mereka bisa langsung mengakses pada link Youtube yang telah diberikan pendidik. Bagi peserta didik yang terkendala sinyal, pendidik biasanya mengirimkan video pembelajaran tersebut secara personal kepada peserta didik tersebut. Selanjutnya menggunakan media ajar aplikasi game belajar, dalam game belajar ini biasanya digunakan bagi pendidik yang mengampu mata pelajaran eksak misalnya mata pelajaran matematika. Game belajar ini sangat membantu peserta didik untuk belajar sambil bermain. Selain dapat mengasah kemampuan eksaknya, peserta didik pun juga senang, karena fiturnya yang menarik dan menyenangkan. Selain itu pendidik juga mengarahkan kepada peserta didik untuk menggunakan KBBI daring/Aplikasi KBBI karena sangat membantu peserta didik dalam belajar kosakata sehingga dapat memperkaya khasanah keilmuwan di bidang mata pelajaran Bahasa Indonesia.

\section{Pelaksanaan Pembelajaran Bahasa Indonesia}

Pada saat pandemi koronavirus adanya kebijakan social distancing dan physical distancing mengharuskan para pendidik dan peserta didik untuk melaksanakan pembelajaran daring. Saat pembelajaran masih dilaksanakan tatap muka di situ terdapat banyak kelebihan, pendidik harus tetap memaksimalkan pembelajaran daring sehingga proses belajar tetap terlaksana. Metode pembelajaran dapat diartikan sebagai cara yang digunakan untuk mengimplementasikan rencana yang sudah disusun dalam bentuk kegiatan nyata dan praktis untuk mencapai tujuan pembelajaran (Pembelajaran, 2003). Metode pembelajaran yang dikembangkan oleh pendidik di MTs Terpadu Karanggede Boyolali ketika pembelajaran khususnya Bahasa Indonesia adalah metode on cameclose came. Metode pembelajaran on came-close came memiliki maksud yaitu selama beberapa pertemuan tidak selalu guru menggunakan media video conference (on) tetapi adakalanya juga hanya memanfaatkan media seperti Whatsapp Grup atau Google Form (close). Metode tersebut cukup efektif dilakukan karena disamping itu tidak membuat peserta didik boros menggunakan kuota internet juga dan membuat mereka tidak harus selalu terpancang di depan video conference, sehingga membuat peserta didik pun merasa sedikit santai, rileks dalam belajar. Selain itu, karena selama pandemi koronavirus untuk menggunakan metode berbasis kelompok itu susah maka setiap pembelajaran pendidik banyak menggunakan metode personal.

Pelaksanaan pembelajaran Bahasa Indonesia di MTs Terpadu Karanggede Boyolali, selama satu bulan selama masa pandemi, pendidik harus mencapai target materi yang harus diselesaikan. Selama semester gasal sebelumnya dalam satu bulan 
pendidik dapat menyelesaikan dua bab materi dari tiga bab materi yang ada. Selanjutnya bab ketiga yang akan disampaikan pendidik pada saat peserta didik sudah diperbolehkan untuk kembali ke pondok, itu pun dengan penyampaian yang tidak seluruhnya disampaikan, hanya saja diambil poin-poin penting yang memang harus dicerna dan diketahui peserta didik. Selebihnya pendidik hanya memberikan arahan kepada peserta didik untuk membaca mandiri materi-materi yang menurut pendidik dapat mereka pahami dengan mudah. Setelah kembali ke pondok pun ketika menuju pembukaan semester genap peserta didik harus kembali lagi ke rumah dan kembali daring atau BDR. Selama semester gasal saat masa pandemi, satu bulan pendidik dapat melakukan pertemuan sebanyak delapan kali pertemuan. Karena memang terbatas hanya menggunakan media daring maka pertemuan pun tidak dapat dilakukan dalam waktu yang lama dalam sekali pertemuan. Bahkan jam mengajar pun juga dipangkas, pembelajaran berlangsung dari pukul 07.30-12.00 saja.

Ketika pendidik memberikan tugas kepada peserta didik, menerapkan kaidah yang bisa dikatakan hampir keduanya asinkron dan sinkron. Dalam pembelajaran asinkron adalah pendekatan belajar mandiri dengan interaksi asinkron untuk mendorong pembelajaran. Email, papan diskusi online, Wikipedia, dan blog adalah sumber daya yang mendukung pembelajaran asinkron. Salah satu contoh pembelajaran asinkron adalah ketika pendidik memberikan materi teks ulasan untuk kelas VIII. Pendidik memberikan tugas untuk membuat teks ulasan dari film pendek yang dikirimkan melalui Whatsapp Group peserta didik. Dari film tersebut pendidik kirimkan dalam dua format yaitu video dan link Youtube. Tentu saja peserta didik dapat kapan saja mengakses tugas yang diberikan pendidik tanpa batasan waktu. Sedangkan dalam pembelajaran sinkron, siswa dan guru berada di tempat yang sama pada waktu yang sama. Ini mirip dengan kelas tatap muka (Chaeruman dalam Kurniasari, 2020). Contoh lain kegiatan pembelajaran sinkron yaitu ketika di awal pembelajaran pendidik sering memberikan kuis singkat kepada peserta didik untuk mereview materi-materi sebelumnya yang harus mereka selesaikan di saat itu juga dan tentunya terbatas dalam waktu pengerjaannya.

Penugasan yang diberikan pendidik biasanya dikirimkan ke Whatsapp Group peserta didik jadi pembelajaran tidak selalu menggunakan video conference. Video conference biasanya digunakan pendidik untuk Kegiatan Belajar Mengajar (KBM) saja. Adapun Langkah-langkah pendidik saat memberikan tugas kepada peserta didik semasa kegiatan pembelajaran dilakukan dari rumah, yaitu:

1. Survei materi yang kira-kira sudah dapat dipahami peserta didik.

2. Mempertimbangkan jenis tugas yang diberikan agar tidak memberatkan karena masih dalam pembelajaran daring.

3. Membuat format tugas biasanya berupa lembar kerja siswa dari peserta didik yang ditulis di kertas/diketik menggunakan laptop kemudian difoto dan kirim kepada pendidik melalui Whatsapp.

4. Pengumpulan tugas diberikan jeda waktu 1 atau 2 hari setelah penyampaian tugas.

5. Setiap pertemuan pendidik tidak selalu memberikan tugas, karena khususnya Bahasa Indonesia guru paham bahwa peserta didik di rumah sudah setiap waktu berada di layar HP/laptop sehingga jika hal tersebut terus menerus berlangusng tentu tidak sehat bagi mata/penglihatan mereka. Maka kadangkala pun pendidik hanya memberikan materi kepada peserta didik untuk membantu mereka tetap belajar layaknya seperti pertemuan di kelas. 


\section{Evaluasi Pembelajaran Bahasa Indonesia}

Evaluasi adalah suatu proses penentuan keputusan tentang kualitas suatu objek atau aktivitas dengan melibatkan pertimbangan nilai berdasarkan data dan informasi yang dikumpulkan, dianalisis dan ditafsirkan secara sistematis. Evaluasi pembelajaran merupakan suatu proses untuk menentukan jasa, nilai atau manfaat program, hasil dan proses pembelajaran.

Dalam evaluasi atau penilaian hasil belajar siswa yang dilakukan pendidik khususnya pada mata pelajaran Bahasa Indonesia yaitu dengan mengadakan peninjuan kembali atau me-review materi dengan diadakannya kuis singkat. Menurut seorang pendidik mata pelajaran Bahasa Indonesia di MTs Terpadu Karanggede Boyolali hal tersebut sudah cukup efektif supaya peserta didik mampu dapat mengingat dan lebih memahami materi yang telah disampaikan.

Untuk ulangan harian guru masih mengadakannya dengan mengirimkan soal melalui Google Form dan meminta peserta didik untuk mengerjakannya di jam pembelajaran berlangsung. Selama adanya pandemi koronavirus ini penilaian yang dapat dilakukan pendidik hanya satu arah saja dan bersifat personal antara pendidik dan peserta didik saja. Jika pun ada penilaian antar teman sejawat maupun berbasis kelompok pada saat pembelajaran dilakukan di rumah seperti ini belum dapat dilakukan.

Berdasarkan hasil respons angket yang diberikan siswa melalui Google Form dengan alamat sebagai berikut:

https://docs.google.com/forms/d/e/1FAIpQLScr3LoEe7pofewxZ8zoOO2u5o3E6WZs

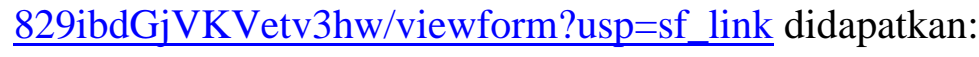

\section{Pembelajaran melalui program Belajar Dari Rumah (BDR) di masa pandemi koronavirus menyenangkan.}

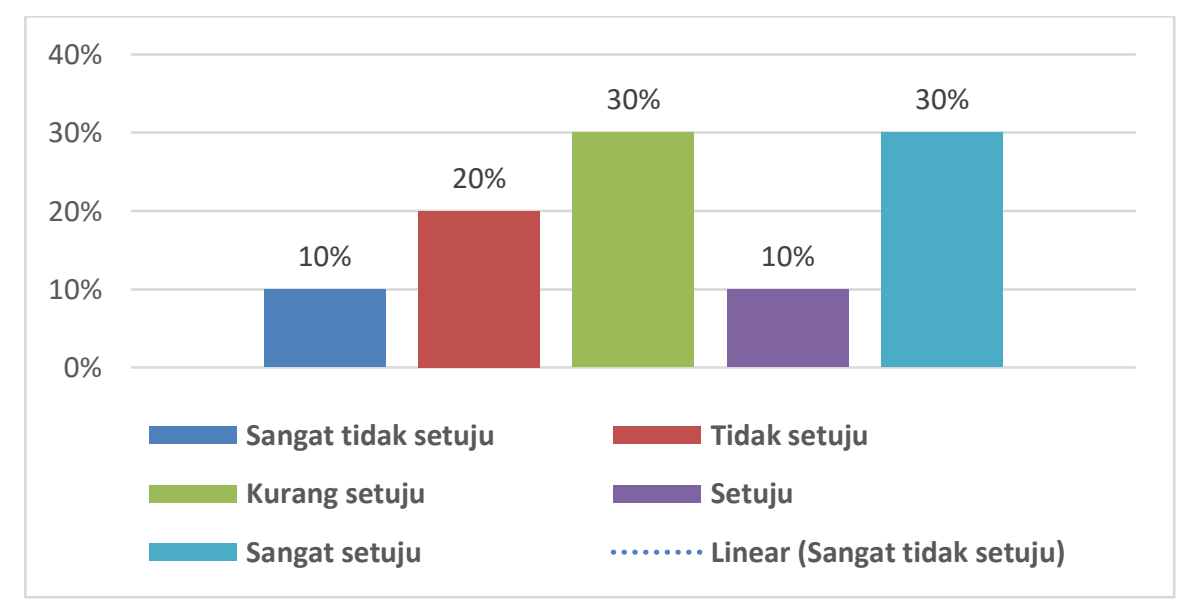

Diagram 1. Keterkaitan Siswa dalam Pembelajaran dari rumah

Dari item pertanyaan ke-1 tentang keterkaitan siswa dalam pembelajaran dari rumah jawaban siswa adalah 10\% sangat tidak setuju, 20\% tidak setuju, 30\% kurang setuju, $10 \%$ setuju, $30 \%$ sangat setuju. 


\section{PRASI JuRnal bahasa, senl, dan PEngadarannya}

VOL. 16 | No. 01 | Juni 2021

ISSN: Print 1693-6124 - Online 2614-1116

Undiksha| DOI: http://dx.doi.org/10.23887/prasi.v16i01.33837 | https://ejournal.undiksha.ac.id/index.php/PRASI

\section{Pembelajaran melalui program Belajar Dari Rumah atau daring mengalami kesulitan.}

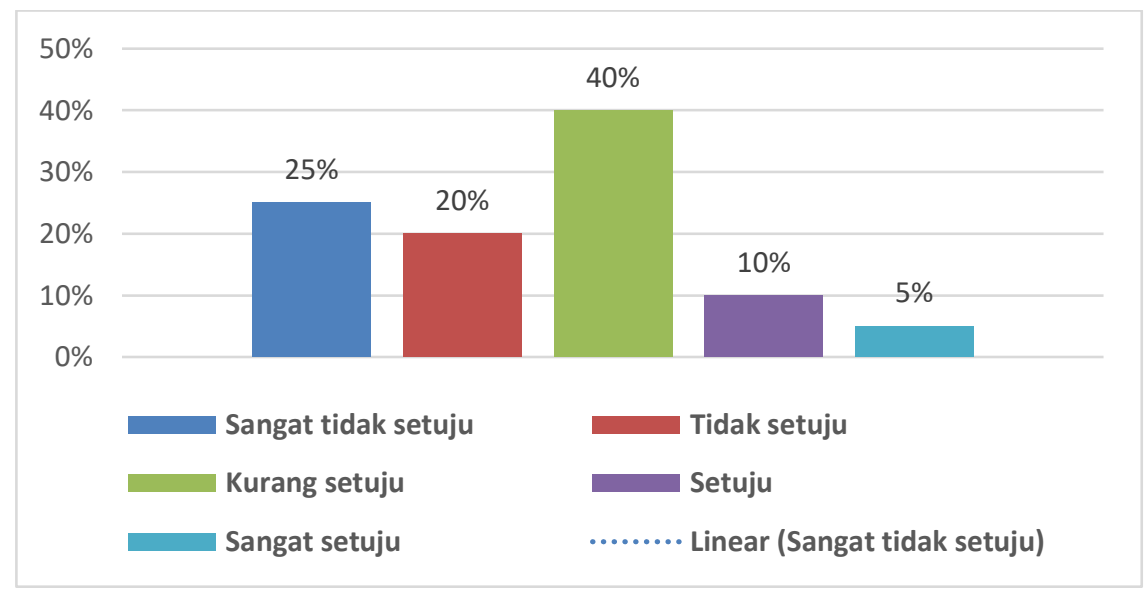

Diagram 2. Kendala Siswa pada saat Belajar Dari Rumah

Dari item pertanyaan ke-2 ini tentang kendala siswa pada saat belajar dari rumah jawaban siswa adalah 25\% sangat tidak setuju, 20\% tidak setuju, 40\% kurang setuju, $10 \%$ setuju, $5 \%$ sangat setuju.

\section{Alasan kesulitan dalam Belajar Dari Rumah (BDR).}

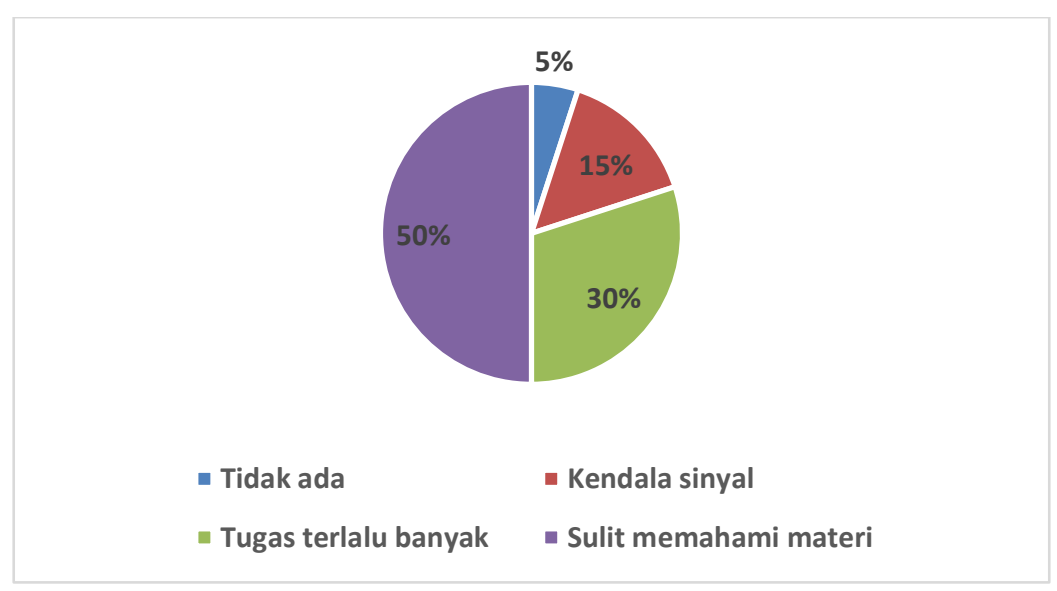

Diagram 3. Kesulitan Siswa pada saat Belajar Dari Rumah

Dari item pertanyaan ke-3 ini tentang kesulitan siswa pada saat Belajar Dari Rumah jawaban siswa adalah 5\% tidak ada, 15\% kendala sinyal, 30\% tugas terlalu banyak, $50 \%$ sulit memahami materi. 


\section{Pendamping belajarmu di rumah.}

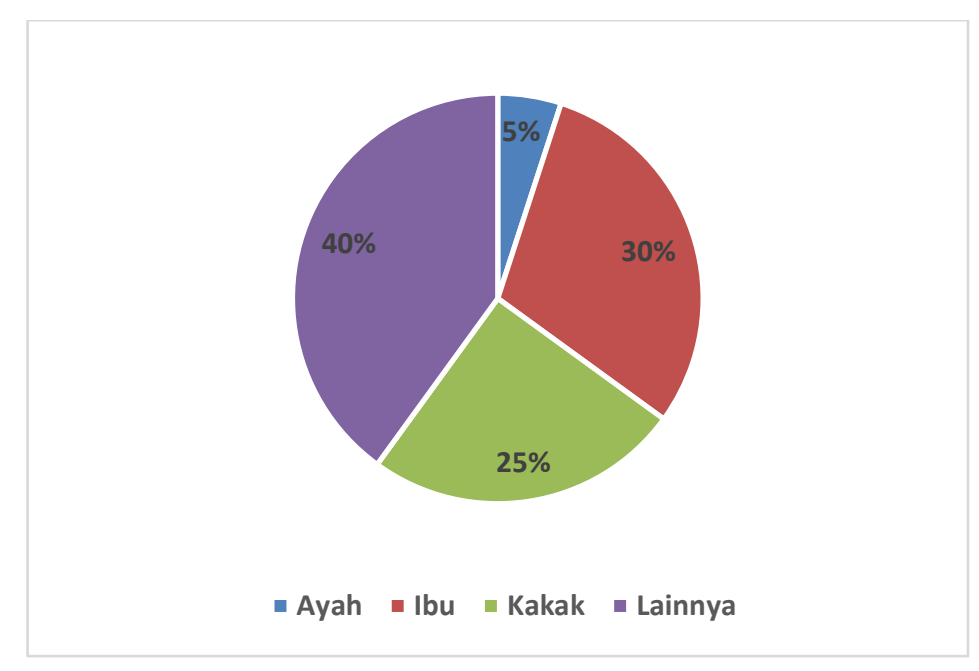

Diagram 4. Pendamping Siswa pada saat Belajar Dari Rumah

Dari item pertanyaan ke-4 ini tentang pendamping siswa pada saat Belajar Dari Rumah jawaban siswa adalah 5\% Ayah, 30\% Ibu, 25\% kakak, 40\% lainnya.

\section{Pembelajaran Bahasa Indonesia sudah sesuai dengan jadwal yang ditentukan.}

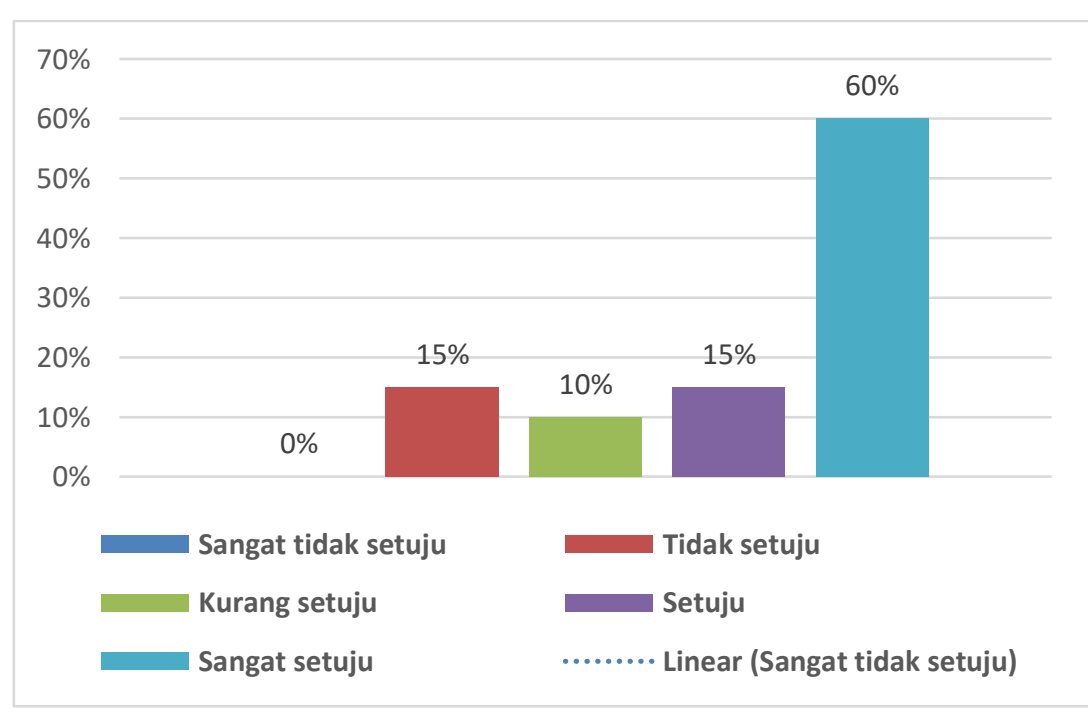

Diagram 5. Kesesuaian Pelaksanaan Pembelajaran

Dari item pertanyaan ke-5 ini tentang kesesuaian pelaksanaan pembelajaran jawaban siswa adalah 15\% tidak setuju, 10\% kurang setuju, 15\% setuju, 60\% sangat setuju. 


\section{PRASI JURNAL BAHASA, SENI, DAN PEngaJARANNYA}

VOL. 16 | No. 01 | Juni 2021

ISSN: Print 1693-6124 - Online 2614-1116

Undiksha| DOI: http://dx.doi.org/10.23887/prasi.v16i01.33837 | https://ejournal.undiksha.ac.id/index.php/PRASI

\section{Pembelajaran Bahasa Indonesia mudah diikuti.}

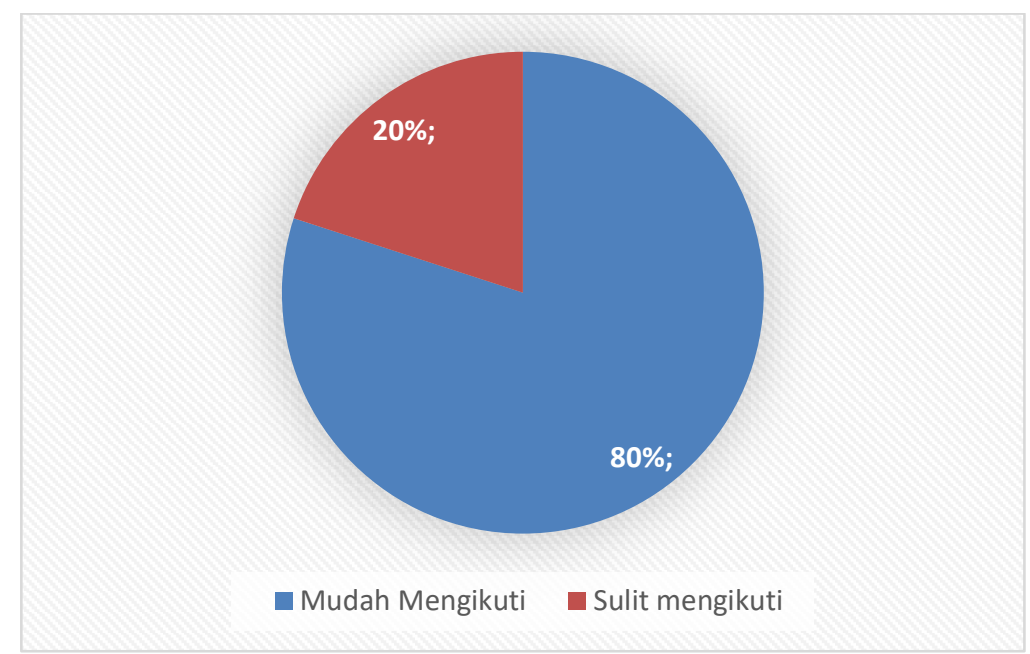

Diagram 6. Penyampaian Materi Bahasa Indonesia

Dari item pertanyaan ke-6 ini tentang penyampaian materi Bahasa Indonesia jawaban siswa adalah $80 \%$ mudah dipahami, $20 \%$ sulit mengikuti.

\section{Penyampaian materi mata pelajaran Bahasa Indonesia dilakukan dengan daring mudah dipahami.}

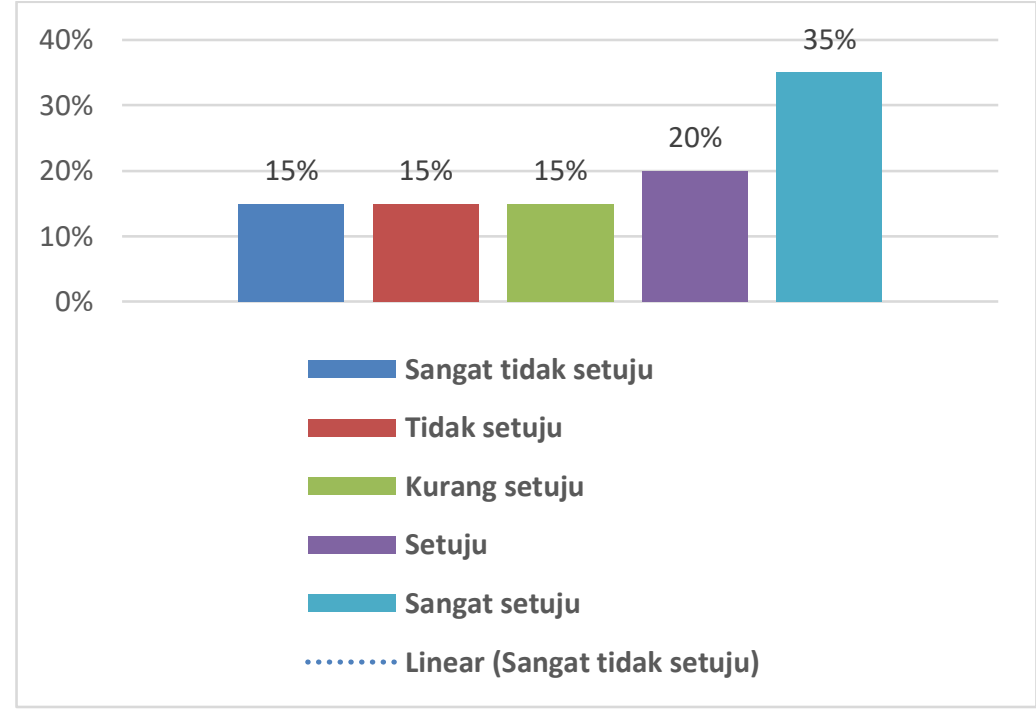

Diagram 7. Pemahaman Materi yang Disampaikan secara Daring

Dari item pertanyaan ke-7 ini tentang pemahaman materi yang disampaikan secara daring jawaban siswa 15\% sangat tidak setuju, 15\% tidak setuju, 15\% kurang setuju, $20 \%$ setuju, $35 \%$ sangat setuju. 


\section{Komunikasi yang dilakukan guru cukup membantu kalian dalam pembelajaran?}

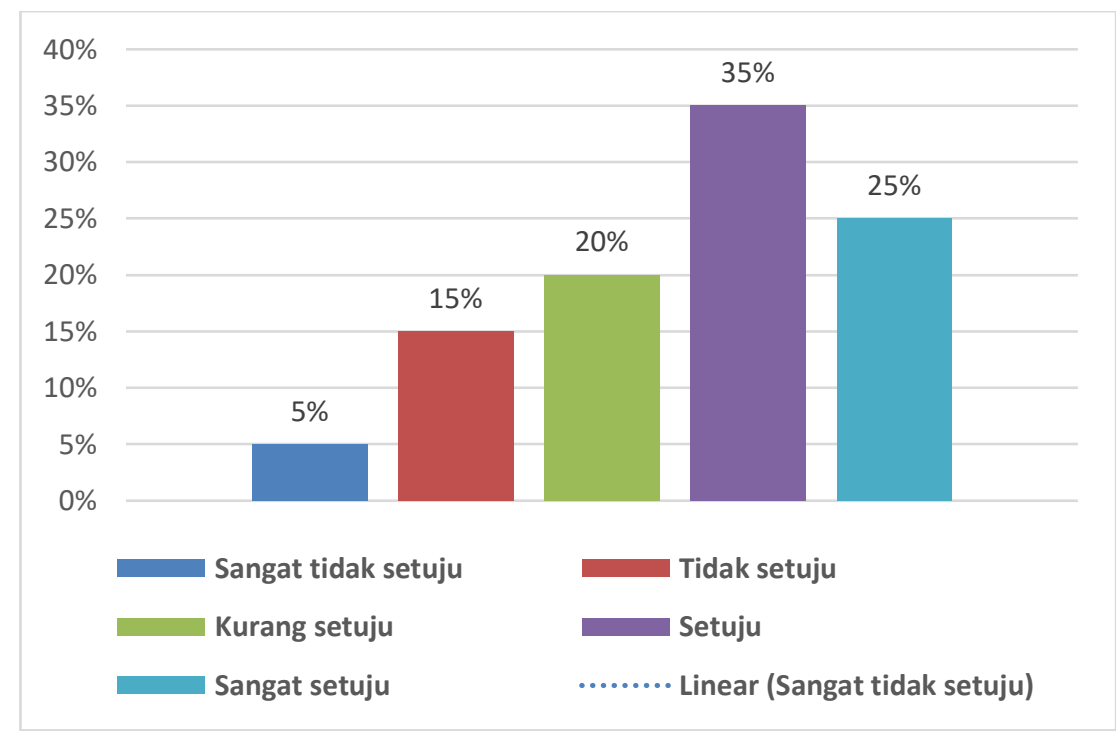

Diagram 8. Komunikasi Siswa saat Pembelajaran Daring

Dari item ke-8 ini tentang komunikasi siswa saat pembelajaran daring jawaban siswa adalah 5\% sangat tidak setuju, 15\% tidak setuju, 20\% kurang setuju, 35\% setuju, $25 \%$ sangat setuju.

\section{Tugas-tugas yang diberikan guru terbilang sulit.}

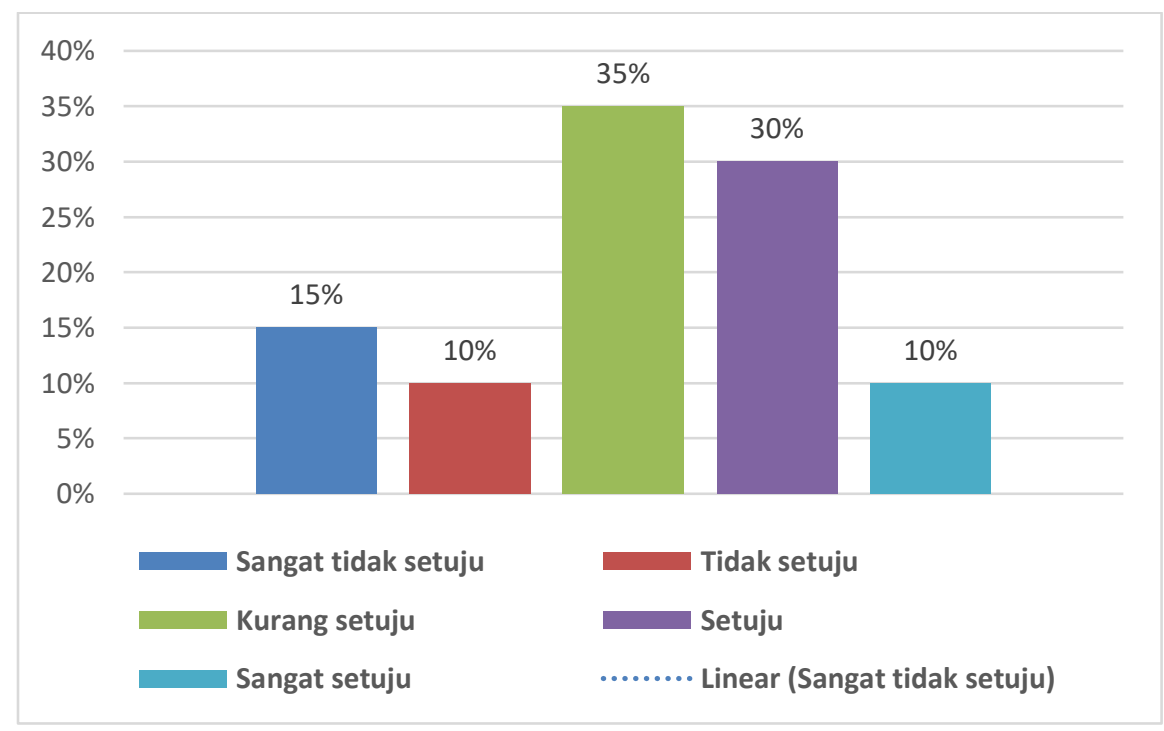

Diagram 9. Penugasan Siswa saat Belajar Dari Rumah

Dari item pertanyaan ke-9 ini tentang penugasan siswa saat Belajar Dari Rumah jawaban siswa adalah 15\% sangat tidak setuju, 10\% tidak setuju, 35\% kurang setuju, $30 \%$ setuju, $10 \%$ sangat setuju. 


\section{Kesulitan dalam mata pelajaran Bahasa Indonesia yang ditemui.}

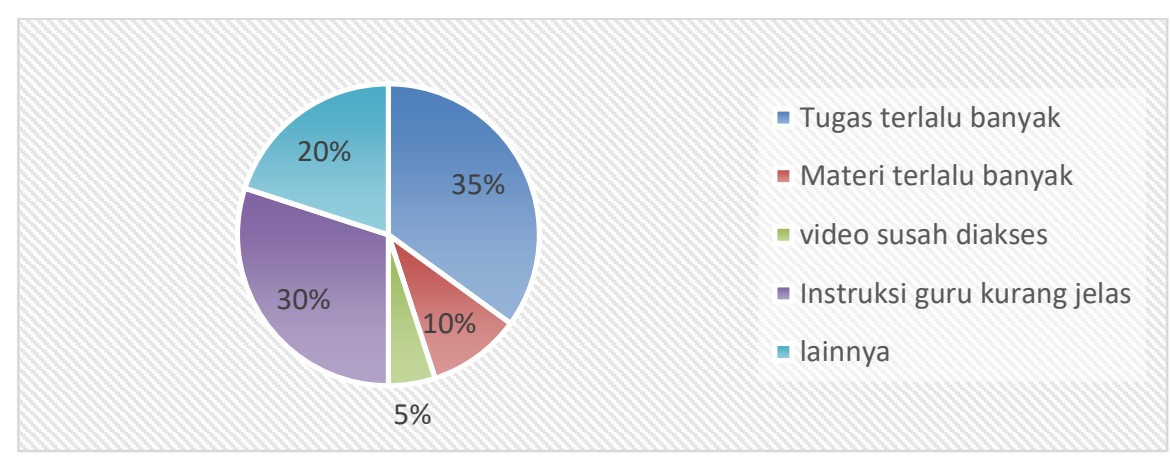

Diagram 10. Kesulitan Siswa pada saat Pembelajaran Bahasa Indonesia

Dari item ke-10 ini tentang kesulitan siswa pada saat pembelajaran Bahasa Indonesia jawaban siswa adalah 35\% tugas terlalu banyak, $10 \%$ materi terlalu banyak, $5 \%$ video susah diakses, $30 \%$ instruksi guru kurang jelas, $20 \%$ lainnya.

\section{Pandanganmu siswa terhadap tugas-tugas pembelajaran yang dilakukan di rumah.}

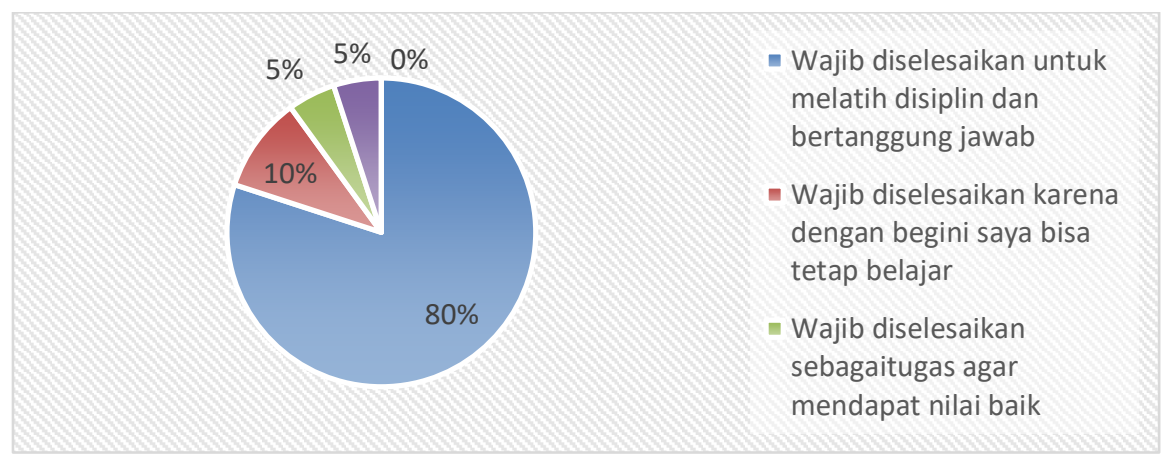

Diagram 11. Pendapat Siswa saat Pembelajaran Daring

Dari item ke-11 ini tentang pendapat siswa saat pembelajaran daring jawaban siswa adalah $80 \%$ menjawab wajib diselesaikan untuk melatih disiplin dan bertanggung jawab, $10 \%$ wajib diselesaikan karena dengan begini saya bisa tetap belajar, 5\% wajib diselesaikan sebagai tugas agar mendapat nilai baik, 5\% wajib diselesaikan untuk menambah wawasan saya.

\section{SIMPULAN}

Berdasarkan hasil penelitian dan pembahasan, maka dapat ditarik simpulan bahwa perencanaan pembelajaran Bahasa Indonesia di MTs Terpadu Karanggede Boyolali sama halnya seperti perencanaan pembelajaran biasanya, yang dimulai dari menyusun perangkat pembelajaran yang disesuaikan dengan kurikulum 2013. Perencanaan berbentuk perangkat pembelajaran yang meliputi KI dan KD untuk Bahasa Indonesia tingkat SMP kelas VIII; menyusun silabus sebagai rancangan proses pembelajaran; menyusun RPP yang disesuaikan dengan masa pandemi yaitu disusun menjadi satu lembar saja yang khusus untuk pembelajaran daring (BDR) dan RPP 
dibuat setiap satu kali pertemuan; menyusun Prota dan Promes, serta membuat kalender akademik untuk menentukan target menyelesaikan setiap bab materi yang akan ditempuh dan menjadi tolak ukur pembuatan Prota dan Promes.

Pelaksanaan pembelajaran Bahasa Indonesia di MTs Terpadu Karanggede Boyolali dengan metode pembelajaran on came-close came. Metode tersebut cukup efektif dilakukan karena di samping tidak membuat peserta didik boros menggunakan kuota internet, juga membuat mereka tidak harus selalu terpancang di depan video conference, sehingga membuat peserta didik pun merasa sedikit santai rileks dalam belajar.

Evaluasi pembelajaran Bahasa Indonesia di MTs Terpadu Karanggede Boyolali untuk mengadakan peninjauan kembali atau meriview materi dilakukan dengan kuis singkat. Untuk ulangan harian pendidik mengadakan dengan cara mengirimkan soal melalui Google Form dan meminta peserta didik untuk mengerjakannya pada saat jam pembelajaran berlangsung.

\section{DAFTAR PUSTAKA}

M., \& Rusimamto, P. (2015). Pengembangan Media Pembelajaran Multimedia Interaktif Berbantuan Software Lectora Inspire Untuk Meningkatkan Hasil Belajar Pada Mata Pelajaran Teknik Listrik Di Smk Negeri 2 Surabaya. Jurnal Pendidikan Teknik Elektro, 5(1), 107-114.

Ahsani, E. L. F. (2020). Strategi Orang Tua dalam Mengajar dan Mendidik Anak dalam Pembelajaran At The Home Masa Pandemi Covid-19. Jurnal Al_Athfal, 3(1), 37-46.

Anggara, D. S., \& Abdillah, C. (2018). Proses Pembelajaran Program Homeschooling Tingkat Sekolah Dasar Di Pkbm Anugrah Bangsa Kota Semarang. EDUKA : Jurnal Pendidikan, Hukum, Dan Bisnis, 3(1). https://doi.org/10.32493/ eduka.v3i1.3802.

Empati, J., Ananda, L. R., \& Kristiana, I. F. (2017). Studi Kasus: Kematangan Sosial Pada Siswa Homeschooling. Empati, 6(1), 257-263.

Hamalik, O. (2004). Proses belajar mengajar. Bumi Aksara.

Hanifah Salsabila, U., Irna Sari, L., Haibati Lathif, K., Puji Lestari, A., \& Ayuning, A. (2020). Peran Teknologi Dalam Pembelajaran Di Masa Pandemi Covid-19. AlMutharahah: Jurnal Penelitian Dan Kajian Sosial Keagamaan, 17(2), 188-198. https://doi.org/10.46781/al-mutharahah.v17i2.138.

Harianto, F. (2017). Hubungan Penggunaan Media Pembelajaran Audio Visual dengan Minat Peserta Didik pada Pembelajaran Pendidikan Agama Islam di SMAN 1 Bangkinang Kota. 14(2).

Keraf, A. S., \& Dua, M. (2001). Ilmu Pengetahuan Sebuah Tinjauan Filosofis (Vol. 22). Kanisius.

Kurniasari, A. dkk. (2020). Analisis Efektivitas Pelaksanaan Belajar Dari Rumah (Bdr) 


\section{PRASI JURNAL BaHASA, SENI, DAN PENGAJARANNYA}

VOL. 16 | No. 01 | Juni 2021

ISSN: Print 1693-6124 - Online 2614-1116

Undiksha| DOI: http://dx.doi.org/10.23887/prasi.v16i01.33837 | https://ejournal.undiksha.ac.id/index.php/PRASI

Selama Pandemi Covid-19. Jurnal Review Pendidikan Dasar: Jurnal Kajian Pendidikan Dan Hasil Penelitian, 6(3), 1-8.

Maiti, \& Bidinger. (1981). Pengembangan Media E-Modul Berbasis Aplikasi Android Materi Komunikasi Sinkron Dan Asinkron Dalam Jaringan Mata Pelajaran Simulasi Dan Komunikasi Digital Kelas X Multimedia Di Smk Negeri 1 Sooko Mojokerto. Journal of Chemical Information and Modeling, 53(9), 1689-1699.

Munawaroh, A. N., Jayadinata, A. K., \& Aeni, A. N. (2017). Jurnal pena ilmiah: vol 2, No 1 (2017). Jurnal Pena Ilmiah, 2(1), 2051-2060. ejournal.upi.edu/index.php/ penailmiah/article/download/3566/pdf\%0A\%0A.

Pembelajaran, M. (2003). Pengertian Pendekatan, Strategi, Metode, Teknik, Taktik, dan Model Pembelajaran. 1.

Pendidikan, M., Kebudayaan, D. A. N., \& Indonesia, R. (2013). Pelaksanaan Kebijakan Pendidikan dalam Masa Darurat Penyebaran Coronavirus Disease (Covid-19). 2013-2015.

Purbawati, C., Rahmawati, L. E., Hidayah, L. N., \& Wardani, L. S. P. (2020). Tingkat Partisipasi Siswa Sekolah Menengah Pertama Dalam Pembelajaran Daring Di Masa Pandemi Covid-19. Refleksi Edukatika : Jurnal Ilmiah Kependidikan, 11(1), 102-108. https://doi.org/10.24176/re.v11i1.4919.

Rahmat, D. (2017). Implementasi Kebijakan Program Bantuan Hukum Bagi Masyarakat Tidak Mampu Di Kabupaten Kuningan. UNIFIKASI : Jurnal Ilmu Hukum, 4(1), 3542. https://doi.org/10.25134/unifikasi.v4i1.478.

Rahmatilah, S., Hidayat, S., \& Apriliya, S. (2017). Media Buku Pop Up Untuk Pembelajaran Bahasa Indonesia Di Kelas Rendah. PEDADIDAKTIKA: Jurnal Ilmiah Pendidikan Guru Sekolah Dasar, 4(1), 139-148.

Rukajat, A. (2018). Teknik Evaluasi Pembelajaran. Deepublish.

Soemanto, Wasty. (2006). Psikologi Pendidikan. Jakarta: PT Rineka Cipta.

Siahaan, M. (2020). Dampak Pandemi Covid-19 Terhadap Dunia Pendidikan. Jurnal Kajian Ilmiah, 1(1), 73-80. https://doi.org/10.31599/jki.v1i1.265.

Suryosubroto, B. (2002). Proses Belajar Mengajar Di Sekolah Wawasan Baru: Beberapa Metode Pendukung Dan Beberapa Komponen Layanan Khusus. PT Rineka Cipta. 